\title{
PROBLEMATIKA DAN TEKNIS PENYELENGARAAN PEMILIHAN KEPALA DAERAH PADA MASA PANDEMI COVID 19
}

\author{
${ }^{1}$ Sarjan, ${ }^{2} \mathrm{Kemal}$ AL Kindi Mulya, ${ }^{3}$ Siti Chadijah \\ Fakultas Hukum Universitas Pamulang. \\ Email: 1saktisarjan@gmail.com, 2kemal_alkindi@yahoo.com, \\ ${ }^{3}$ Schadijah08@gmail.com
}

Received: Juni 2020/Revised: Juli 2020/Accepted: Juli 2020

\begin{abstract}
ABSTRAK
Negara Indonesia adalah negara yang menganut sistem demokrasi. Dalam menjalankan pemilihan umum sudah menjadi keharusan yang telah diamanatkan oleh UUD 1945 sesuai dengan bunyi Pasal 22E Ayat (1), (2), (3), (4), (5) dan (6). Keharusan ini menjadikanya syarat dalam memilih Anggota Dewan Perwakilan Daerah. Pemerintah melalui Perppu Nomor 2 Tahun 2020 menetapkan bahwa Pemilihan Umum Kepala Daerah (Pilkada) akan diselenggarakan pada 9 Desember 2020. Namun pada tahun 2020 ini menjadi tahun yang tidak seperti tahun-tahun sebelumnya, karena di tahun ini secara khusus Indonesia sedang dalam masa pandemi Covid-19 dan secara luas Covid-19 sudah menjadi wabah dunia saat ini. Awalnya Pilkada 2020 akan diselenggarakan pada tanggal 23 September 2020 untuk memilih 9 gubenur, 224 bupati, dan 37 walikota secara serentak. Dalam melakukan analisis ini, penulis menggunakan pendekatan normatif yuridis yaitu pendekatan yang ditujukan untuk mengkaji asas-asas hukum, dan sestematika hukum. Pembahsan yang akan penulis uraikan adalah bagaimana pilkada berdasarkan peraturan perundang-undangan dan permasalahan yang akan timbul dalam penyelenggaraan pilkada saat pandemi, serta teknik penyelenggaraanya, dengan tujuan supaya mengetahui batas-batas penerapan hukum terhadap pemilihan umum dimasa pandemi Covid19.
\end{abstract}

\section{Kata kunci: Pemilihan Kepala Daerah, Pandemi Covid-19}

\section{ABSTRACT}

Indonesia is a country that adopts a democratic system. In carrying out general elections it is a necessity that has been mandated by the 1945 Constitution in accordance with the sounds of Article 22E Paragraphs (1), (2), (3), (4), (5) and (6). This requirement makes it a condition in selecting Regional Representative Council Members. The 
government, through Perppu No. 2 of 2020 , remains unmoved that the regional head election will be held on 9 December 2020. Apparently this year 2020 has become a year unlike previous years, because in this year specifically Indonesia is in the Covid-19 pandemic and broadly Covid-19 has become a world epidemic today. Initially the 2020 elections will be held on September 23, 2020 to select 9 governors, 224 regents, and 37 mayors simultaneously. In conducting this analysis, the author uses a juridical normative approach, which is an approach aimed at studying the principles of law, and legal schemes. The discussion that the author will elaborate on is how the election is based on laws and regulations, also what kind of problems will arise in the holding of the elections during a pandemic, and what kind of implementation techniques, In order to know the limits of the application of the law to elections in the Covid-19 pandemic.

\section{Keywords: Local Elections, Covid-19 pandemic}

\section{PENDAHULUAN}

Banyak orang yang yakin bahwa ilmu pengetahuan dan teknologi memiliki jawaban bagi semua masalah manusia dimuka bumi ini. Para ilmuan dan teknis bekerja, serta mereka akan menciptakan surga bagi kehidupan makluk hidup di mukabumi ini. Namun ilmu pengetahuan bukanlah usaha yang dilangsungkan secara langsung disuatu rana moral atau spiritual yang lebih tinggi dari pada segala aktivitas lain dikehidupan manusia. Seperti semua bagian lainnya yang berada pada kebudayaan kehidupan manusia, ilmu pengetahuan dibentuk oleh kepentingan-kepentingan ekonomi, politik, dan agama (Yuval Noah Harari, 2017: 323).

Pada tanggal 8 Agustus 2006, sejarah dunia mencatat bahwa Indonesia mengawali ketransparanandata sequencing DNA virus H5N1 yang sedang melanda dunia. Yakni dengan cara mengirim data yang tadinya disimpan di WHO, dikirim pula ke "Gene Bank". (Siti Fadilah Supari, 2008: 18). Mulai saat ini, tanggal 20 Desember 2006, kita tidak akan mengirimkan spesimen virus Flu Burung dari Indonesia ke WHO CC lagi, selama mekanismenya masih mengikuti GISN. Mekanisme yang sangat imperialistik ini harus dirubah menjadi mekanisme: yang adil dan transparan, sehingga negara penderita tidak sangat dirugikan seperti saat ini (Ibid). Maka, memasuki gerbang tahun 2007 dengan mantap dan pasti saya mengambil keputusan, virus tidak akan kita kirim lagi ke WHO CC. Kita harus bisa mengerjakan sendiri. Dan niat kami semakin 
menggebu untuk mengatakan pada dunia, bahwa WHO telah menggunakan aturan-aturan yang tidak adil dan itu harus dirubah atau kami berhenti mengirim virus (Ibid, :23-24).

Indonesia pertama kali mengkonfirmasi kasus Corona virus/Covid-19 pada bulan Maret lalu. Penetapan status Pandemi Covid-19 oleh Organisasi Kesehatan Dunia (World Health Organization) berdasarkan jumlah penyebaran virus bertambah signifikan dan berkelanjutan secara global, hal ini direspon oleh Pemerintah Indonesia dengan menetapkan status wabah Covid-19 sebagai Bencana Nasional pada tanggal 14 Maret yang tertuang dalam Keputusan Presiden Nomor 12 Tahun 2020 tentang Penetapan Bencana Non Alam Penyebaran Corona Virus Disease 2019 (COVID-19) Sebagai Bencana Nasional. Selanjutnya Presiden membentuk Gugus Tugas Percepatan Penanganan Covid-19 dalam rangka mengkoordinasikan kapasitas pusat dan daerah (Siti Chadijah, 2020 : 859).

Pemilihan Umum di tengah-tengah Covid-19 menjadi persoalan tersendiri yang sedang membutuhkan ruang khusus. Karena akan banyak sudut pandang dari berbagai lapisan masyarat yang bersepakat dengan tetap melakukan pemilihan umum atau juga yang tidak bersependapat. Sehingga dengan semakin banyaknya diskursus soal pemilihan umum ini sehingga besar kemungkinan akan lahir pertanya seperti apakah pemilihan umum akan tetap diselenggarakan pada saat pandemi covid-19? Untuk menjawab pertanyaan diatas makan perlu melakukan sebuah tinjaun yuridis sebagai landasan atau pijakan dalam penyelenggaraan pemilihan umum saat ini. Walaupun pada akhirnya kebijakan tersebut akan banyak menuai pro dan kontra.

Sedangkan Indonesia menjadi 1 dari 55 negara yang memilih untuk menunda pelaksanaan pemilu lokal. Sedianya, berdasarkan Pasal 201 ayat (6) UU No. 10 Tahun 2016, Indonesia memiliki agenda untuk menyelenggarakan Pemilihan Umum Kepala Daerah (Pilkada) di tanggal 23 September 2020. Namun, melalui Peraturan Pemerintah Pengganti Undang-Undang No. 2 Tahun 2020 (Selanjutnya disingkat Perppu 2/2020), Pemerintah Indonesia memutuskan untuk menjadwalkan ulang Pilkada menjadi tanggal 9 Desember 2020. Keputusan ini menimbulkan perdebatan di masyarakat, terutama di kalangan akademisi. Penjadwalan pilkada di bulan Desember 2020 dinilai tak realistis. Karena faktanya, hingga 16 Mei 2020 jumlah 
kasus positif Covid-19 terus meningkat secara nasional (Richard Kennedy, Bonaventura Pradana Suhendarto, 2020 : 189 ).

Pertimbangan dikeluarkannya Perppu No.2/2020 bahwa dalam rangka penanggulangan penyebaran Corona Virus Disease 2019 (COVID-19) sebagai bencana nasional perlu diambil kebijakan dan langkah-langkah luar biasa baik di tingkat pusat maupun daerah termasuk perlunya dilakukan penundaan tahapan pelaksanaan pemilihan gubernur dan wakil gubernur, bupati dan wakil bupati, serta walikota dan wakil walikota serentak tahun 2020 agar pemilihan gubernur dan wakil gubernur, bupati dan wakil bupati, serta walikota dan wakil walikota tetap dapat berlangsung secara demokratis dan berkualitas serta untuk menjaga stabilitas politik dalam negeri.

\section{PERMASALAHAN}

Berdasarkan yang penulis paparkan diatas maka yang menjadi pokok permasalahan adalah sebagai berikut:

Bagaimana problem pemilihan kepala daerah dan teknis penyelengaraannya pada masa pandemi Covid-19?

\section{METODELOGI PENELITIAN}

Pada metode penelitian ini, peneliti memaparkan jenis penelitian yang digunakan normatif yuridis, metode pendekatan perundang-undangan, lebih menitikberatkan kepada tinjauan kepustakaan karena menggunakan bahan sekunder sebagai bahan utamanya yaitu peraturan perundang-undangan, buku-buku, hasil pengkajian sebelumnya yang masih berkaitan dengan objek kajian.

\section{PEMBAHASAN}

\section{Pilkada berdasarkan Peraturan Perundang undangan}

Di dalam konstitusi menjelaskan dasar penyelenggaraan pemilihan umum yakni: "Pemilihan umum diselenggarakan untuk memilih anggota Dewan Perwakilan Rakyat, Dewan Perwakilan Daerah, Presiden dan Wakil Presiden dan Dewan Perwakilan Rakyat Daerah", yang dilaksanakan secara langsung, umum, bebas, rahasia, jujur, dan adil setiap lima tahun sekali (Pasal 22E ayat (2) UUD 1945). Juga penyelenggaraan pilkada yakni: "Gubernur, Bupati, dan Walikota masing-masing sebagai kepala pemerintahan daerah provinsi, kabupaten, dan kota dipilih secara demokratis" (Pasal 18 ayat (4) UUD 1945). 
Pada kurun tahun 1999 - 2002 (Pasca reformasi 1998), UndangDasar 1945 (UUD 1945) mengalami 4 kali amandemen (19 Oktober 1999; 18 Agustus 2000; 10 November 2001; dan 10 Agustus 2002). Implikasinya, desain sistem politik Indonesia mengalami perubahan signifikan perubahan mendasar terkait dengan Pemilihan Umum (Pemilu), dimulai dari Pemilihan Presiden dan Wakil Presiden secara langsung dalam amandemen ketiga dan keempat UUD 1945. Perubahan selanjutnya adalah terkait Pemilihan Kepala Daerah secara langsung (Pilkada langsung), yang pengaturannya juga berubah-ubah. Pertama, Pilkada diatur dalam UU Nomor 32 Tahun 2004 Tentang Pemerintahan Daerah. Perubahan selanjutnya adalah terkait Pemilihan Kepala Daerah secara langsung (Pilkada langsung), yang pengaturannya juga berubah-ubah. Pertama, Pilkada diatur dalam UU Nomor 32 Tahun 2004 Tentang Pemerintahan Daerah. Kedua, Pilkada dimasukkan ke dalam UU Nomor 22 Tahun 2007 tentang Penyelenggara Pemilihan Umum. Ketiga, tahun 2008, pengaturan Pilkada kembali diubah dalam UU Nomor 12 Tahun 2008 Tentang Perubahan Kedua Atas Undang-Undang Nomor 32 Tahun 2004Tentang Pemerintahan Daerah. Salah satu terobosan utama dalam perubahan perubahan itu adalah dilaksanakannya Putusan Mahkamah Konstitusi (MK) Nomor 5/PUU-V-2007 yang membolehkan munculnya calon perseorangan sebagai kontestan Pilkada (Mohammad Saihu, 2020 : 5).

Selanjutnya tahun 2014 terjadi perdebatan politik di DPR yang berujung pada Penetapan Peraturan Pemerintah Pengganti UU Nomor 1 Tahun 2014 Tentang Pemilihan Gubernur, Bupati, Dan Walikota. Memasuki awal tahun 2015 keluarlah UU Nomor 1 Tahun 2015 UU Nomor 1 Tahun 2014 Tentang Pemilihan Gubernur, Bupati, Dan Walikota. Klimaknya, pada tanggal 17 Pebruari 2015, Sidang Paripurna DPR RI menetapkan UU Nomor 8 Tahun 2015 tentang Perubahan Atas UU Nomor 1 Tahun 2015 Tentang Penetapan Peraturan Pemerintah Pengganti UU Nomor 1 Tahun 2014 Tentang Pemilihan Gubernur, Bupati, Dan Walikota. Selanjutnya, pada 18 Maret 2015, UU ini disahkan dan menandai berlangsungya Pilkada langsung dan serentak pertama di Indonesiapada 9 Desember 2015 yang diikuti oleh 269 daerah (ibid, 2019: 3-4).

Menyikapi penundaan beberapa tahapan pilkada pada masa pandemic Covid-19 dapat menimbulkan berbagai dampak dalam penyelenggaraannya, baik yang sifatnya positif maupun negatif. Dampak positif misalnya, penundaan ini memberikan ruang bagi calon 
independen untuk menyiapkan persyaratan dukungan sebagai calon perseorangan. Partai politik juga bisa relatif mengalami relaksasi dalam melakukan proses rekrutmen calon kepala daerah. Permasalahannya, dampak positif itu tidak terlalu signifikan mengingat tenggang waktu perubahan jadwal penyelenggaraan hanya bergerser tiga bulan, dari 23 September menjadi 9 Desember 2020. Perubahan jadwal ini dianggap dipaksakan mengingat kenaikan jumlah kasus positif COVID-19 belum melandai dan usai. Jika mengutip pendapat (Andrian Habibi, 2020 : 168), pada makalah pemilu dan Covid-19 yang diterbitkan Internasional IDEA yang diterjemahkan oleh Perkumpulan Untuk Demokrasi (Perludem) menjadi dalil pustaka kepemiluan. Jawaban kebijakan belum ditemukan. Secara tidak langsung, Internasional IDEA hanya memberikan saran dan menyerahkan pilihan kebijakan kepada kita. Tetap pilkada atau ditunda saja.

Perppu No.2/2020 mengatur 3 perubahan mendasar tentang penyelenggaraan Pilkada, yaitu: (1) Pasal 120 yang menyatakan faktor bencana non-alam sebagai alasan penundaan rangkaian pilkada; (2) Pasal 122A berkaitan dengan penundaan dan penetapan pilkada lanjutan ditetapkan berdasarkan kesepakatan Komisi Pemilihan Umum (KPU), Pemerintah, dan Dewan Perwakilan Rakyat Republik Indonesia (DPR RI); (3) berdasarkan Pasal 201 A, Pilkada yang semula dijadwalkan pada September 2020 ditunda dan dilaksanakan pada bulan Desember 2020 karena alasan bencana non-alam pandemi Covid-19, bila pada bulan Desember 2020 pilkada belum dapat dilaksanakan, maka dapat ditunda kembali sesuai prosedur Pasal 122A (Richard Kennedy \& Bonaventura Pradana Suhendarto, 2020 : 189).

Selanjutnya Pasal 201A menerangkan sebagai berikut:

(1) Pemungutan suara serentak sebagaimana dimaksud dalam Pasal $2 \mathrm{Ol}$ ayat (6) ditunda karena terjadi bencana nonalam sebagaimana dimaksud dalam Pasal 120 ayat (1).

(2) Pemungutan suara serentak yang ditunda sebagaimana dimaksud pada ayat (l) dilaksanakan pada bulan Desember $2 \mathrm{O} 2 \mathrm{O}$.

(3) Dalam hal pemungutan suara serentak sebagaimana dimaksud pada ayat (2) tidak dapat dilaksanakan, pemungutan suara serentak ditunda dan dijadwalkan kembali segera setelah bencana nonalam sebagaimana dimaksud pada ayat (1) 
berakhir, melalui mekanisme sebagaimana dimaksud dalam Pasal 122 A.

Dalam kajian negara hukum, negara harus mampu merespon keadaan yang dimanifestasikan dalam wujud peraturan perundangan-undangan sebagai jaminan konstitutisonalitas penundaan Pilkada 2020. Secara original intens, peraturan tersebut harus mampu bertindak untuk melindungi rakyat dan menjamin kesejahteraan (Pembukaan UUD NRI Tahun 1945).

Jika berpijak kepada konstitusional maka pada Pasal 18 ayat (4) UUD 1945 yang merupakan kebijakan hukum terbuka, dalam arti membuka peluang pembuat undang-undang untuk menafsirkan lebih lanjut. Saat ini, DPR sebagai pembuat undang-undang bersama pemerintah nampaknya telah sepakat dengan penafsiran pilkada secara langsung dipilih oleh rakyat. Hal itu nampak dalam Pasal 1 UU No. 8 Tahun 2015 yang menyatakan bahwa pilkada dilangsungkan secara langsung dan demokratis. Maka apabila ingin menggunakan alternatif pilkada tidak langsung, DPR harus melakukan perubahan terhadap UU Pilkada terlebih dahulu agar dapat dilangsungkan pilkada tidak langsung. Jika melihat dalam konteks keadaan genting, memaksa dan ketidakmampuan Undang-Undang Pilkada menyikapi keadaan saat ini, kebijakan dalam bentuk Peraturan Pemerintah Pengganti Undang-Undang adalah hal yang tepat. Hal tersebut disandarkan kepada Pasal 22 Undang-Undang Dasar Negara Republik Indonesia bahwa "Dalam hal ihwal kegentingan yang memaksa, Presiden berhak menetapkan peraturan pemerintah sebagai penggati Undang-Undang." (Rezky Panji Perdana Martua Hasibuan, 2020 : 127).

\section{Penyelenggaraan dan Teknis Pilkada Saat Pandemi}

\section{A. Pemilihan Kepala Daerah secara Langsung}

Secara teknis sebagai antisipasi penyebaran covid-19, Komisi Pemilihan Umum telah mengeluarkan kebijakan yang tertuang di dalam Keputusan KPU Nomor 179/PL.02-Kpt/01/KPU/III/2020 tentang Penundaan Tahapan Pemilihan Gubernur dan Wakil Gubernur, Bupati dan Wakil Bupati, dan/atau WaliKota dan Wakil WaliKota Tahun 2020. Keputusan tersebut secara garis besar terdapat 4 tahapan penyelenggaraan pemilihan kepala daerah yang ditunda meliputi pelantikan panitia pemungutan suara, verifikasi syarat dukungan calon perseorangan, pembentukan Panitia Pemuktahiran Data Pemilih, serta pemuktahiran dan penyusunan daftar pemilih. 
Melihat kedalam muatan materinya, keputusan tersebut hanya terbatas kepada penundaan penyelenggaraan teknis pilkada sampai tahap penetapan daftar pemilih, namun tahapan penyeleggaran pilkada serentak tetap akan dilaksanakan pada September 2020. Ketentuan tersebut disandarkan kepada maklumat yang tertuang dalam Pasal 201 ayat (6) Undang-Undang Nomor 10 Tahun 2016 tentang perubahan kedua atas UU Nomor 1 Tahun 2015 tentang Pemilihan Gubernur, Bupati, dan Walikota. (Rezky Panji Perdana Martua Hasibuan, 2020 : 123).

Pasal 120 (1) Perppu No.2/2020 mengatur dalam hal pada sebagian wilayah Pemilihan, seluruh wilayah Pemilihan, sebagian besar daerah, atau seluruh daerah terjadi kerusuhan, gangguan keamanan, bencana alam, bencana nonalam, atau gangguan lainnya yang mengakibatkan sebagian tahapan penyelenggaraan Pemilihan atau Pemilihan serentak tidak dapat dilaksanakan, dilakukan Pemilihan lanjutan atau Pemilihan serentak lanjutan. Kemudian pada ayat (2) Pelaksanaan Pemilihan lanjutan atau Pemilihan serentak lanjutan sebagaimana dimaksud pada ayat (1) dimulai dari tahapan penyelenggaraan Pemilihan atau Pemilihan serentak yang terhenti. Pasal 122A (l) Pemilihan serentak lanjutan sebagaimana dimaksud dalam Pasal 120 dilaksanakan setelah penetapan penundaan tahapan pelaksanaan Pemilihan serentak dengan Keputusan KPU diterbitkan serta (2) Penetapan penundaan tahapan pelaksanaan Pemilihan serentak serta pelaksanaan Pemilihan serentak lanjutan sebagaimana dimaksud pada ayat (1) dilakukan atas persetujuan bersama antara KPU, Pemerintah, dan Dewan Perwakilan Rakyat. Mengenai Ketentuan lebih lanjut mengenai tata cara dan waktu pelaksanaan Pemilihan serentak lanjutan diatur dalam Peraturan KPU.

Pasal 201A (1) Pemungutan suara serentak sebagaimana dimaksud dalam Pasal $2 \mathrm{Ol}$ ayat (6) ditunda karena terjadi bencana nonalam sebagaimana dimaksud dalam Pasal 120 ayat (1). (2) Pemungutan suara serentak yang ditunda sebagaimana dimaksud pada ayat (1) dilaksanakan pada bulan Desember 2O2O. (3) Dalam hal pemungutan suara serentak sebagaimana dimaksud pada ayat (2) tidak dapat dilaksanakan, pemungutan suara serentak ditunda dan dijadwalkan kembali segera setelah bencana nonalam sebagaimana dimaksud pada ayat (1) berakhir, melalui mekanisme sebagaimana dimaksud dalam Pasal 122A (Perpu No.2/2020).

Pemilihan Kepala Daerah atau yang sering disebut Pilkada dalam penyelenggaraanya di Indonesia merupakan sebuah polemik di 
masyarakat yang sampai dengan saat ini belum terselesaikan. Di Indonesia dikenal dua sistem penyelenggaraan Pemilihan Kepala Daerah (Pilkada), yaitu Pilkada secara tidak langsung yang dilakukan pada masa awal kemerdekaan serta Pilkada secara langsung sesudah era reformasi.

\section{Kelebihan Pilkada Langsung Oleh Rakyat}

1. Rakyat pemilih benar-benar mendapat kekuasaan memilih langsung kepala daerah. Tidak diwakilkan kepada siapapun. (one man one vote).

2. Mengenal kepala daerah secara lebih dekat dan nyata.

3. Mengetahui visi dan misi calon kepala daerah secara lebih detil.

4. Pemerintah memiliki legitimasi yang kuat.

5. Satu suara rakyat sangat berharga sehingga kepala daerah akan fokus pada kepentingan rakyat.

6. Pilkada langsung bisa menjadi alat partisipasi langsung rakyat, memahami dan mengerti pentingnya politik.

7. Pemberdayaan sumber daya yang dimiliki oleh kepala daerah akan menjadi semakin efektif.

8. Pihak ketiga akan tereliminasi, karena calon kepala daerah langsung berkomunikasi dengan rakyat.

9. Track record dan prestasi seorang calon kepala daerah akan menjadi nilai jual yang penting terhadap masyarakat pemilih.

10. Mendorong kedewasaan partai politik dan membuat partai akan semakin mendengar aspirasi rakyat secara langsung. Mempertimbangkan calon yang benar-benar disukai oleh rakyat perlu ditambahkan sumbernyanya saja

Dengan demikian penulis menilai terdapat Kelamahan Pilkada Langsung Oleh Rakyat

1. Kepala daerah rawan disusupi kepentingan pemodal yang punya kepentingan tertentu.

2. Butuh biaya yang besar untuk berkampanye dan bertatap muka dengan masyarakat.

3. Pemilih atau rakyat akan menjadi individualis dan matrealistik.

4. Berpotensi menimbulkan konflik horizontal dan vertikal di antara basis pendukung para calon.

5. Rawan penyalahgunaan APBD oleh petahana karena akan kembali bertarung dalam pilkada berikutnya

\section{B. Pemilihan Kepala Daerah oleh DPRD}


Pilkada tidak langsung merupakan sistem pemilihan kepala daerah yang dipilih oleh DPRD atau yang dikenal dengan sistem perwakilan (Hutapea, 2015). Sistem ini bukanlah pola baru, tetapi pernah digunakan dalam sejarah perkembangan pilkada di Indonesia. Sebut saja dengan UU No. 1 Tahun 1957 tentang Pokok-Pokok Pemerintah Daerah, UU No. 18 Tahun 1965 tentang Pokok-Pokok Pemerintahan Daerah, dan UU No. 22 Tahun 1999 tentang Pemerintah Daerah menggunakan mekanisme keterwakilan DPRD sebagai pemilih kepala daerah Saraswati (dalam Richard Kennedy \& Bonaventura Pradana Suhendarto, Op.Cit, 2020 : 193-194).

Sejalan dengan itu, Bagir Manan pun berpendapat bahwa pasal amandemen tersebut telah sesuai dengan semangat mewujudkan pembentukan pemerintahan daerah yang mandiri dan demokratis. Sehingga pilkada pun merupakan bagian dari kewenangan pemerintah daerah untuk menyelenggarakan sesuai adat istiadat maupun asal usul daerah tersebut. Kemudian apabila dicermati, ketentuan pasal tersebut merupakan rezim pemerintah daerah, sebab pembahasan dan rumusannya berada di luar Pasal 22E UUD 1945 yang merupakan dasar konstitusional pemilu (Ibid).

Oleh karenanya, ketentuan tersebut perlu dipahami secara luas dan bukan sekedar pemahaman sempit. sistem ini sebenarnya pernah dilakukan dalam sejarah pilkada di Indonesia. UU No. 1 Tahun 1945 tentang Kedudukan Komite Nasional Daerah memberikan mandat kepada pemerintah pusat untuk memilih dan mengangkat kepala daerah. Begitu pula dengan UU No. 22 Tahun 1948 tentang Penetapan Aturan-Aturan Pokok Mengenai Pemerintah Sendiri di Daerah-Daerah Berhak Mengatur dan Mengurus Rumah Tangganya Sendiri maupun UU No. 5 Tahun 1974 tentang Pokok-Pokok Pemerintahan Daerah memberikan mandat kepada DPRD untuk mengusulkan beberapa calon kepala daerah kepada pemerintah pusat untuk dipilih dan diangkat menjadi kepala daerah tetap (Richard Kennedy \& Bonaventura Pradana Suhendarto, 2020 : 192).

Di tengah situasi pandemi Covid-19 ini (mungkin juga bencana atau kedaruratan yang lain), masih relevan membangun opsi pilkada tidak langsung. Selain karena sistem ini sama-sama demokratisnya sesuai dengan UUD 1945 maupun mendorong dalam rangka pengembangan otonomi daerah, sistem ini memiliki beberapa kelebihan. Sistem ini dinilai lebih efektif dan efisien, sebab cara pemilihannya pun sederhana. Meskipun sederhana, proses yang dilakukan cukup ketat dimana salah satunya ada mekanisme uji 
publik oleh para pakar/ ahli maupun tokoh daerah. Ini semua dilakukan untuk menjamin dan mewujudkan kepala daerah dengan kualitas yang tinggi dan berintegritas. Kemudian, sistem ini cenderung lebih hemat biaya karena tidak perlu mencetak surat suara kertas banyak dan biaya-biaya logistik maupun operasional yang tinggi. Biaya tinggi yang awalnya untuk pilkada langsung, dapat dialokasikan untuk pengembangan daerah dan dapat digunakan untuk menekan penyebaran Covid-19 (Ibid , : 195).

Dengan demikian penulis menyimpulkan kelebihan dan kelemahan pemilihan oleh DPRD sebagai berikut:

\section{Kelebihan Pilkada oleh DPRD}

Anggaran yang dibutuhkan menjadi lebih murah.

Menghilangkan potensi konflik horizontal di kalangan masyarakat.

Tidak ada money politics hingga ke basis masyarakat.

Proses pemilihan kepala daerah menjadi lebih cepat tidak ada penghitungan suara yang memakan waktu lama.

\section{Kekurangan Pilkada oleh DPRD}

Calon kepala daerah tidak dikenal rakyatnya.

Politik uang hanya terjadi di elit partai atau daerah.

Rakyat tidak dilibatkan dalam proses politik atau kurang demokratis.

Kebijakan yang dibuat tidak fokus kepada kepentingan rakyat tetapi lebih kepada kepentingan elit partai di daerah.

Rawan terjadinya dinasti politik di daerah karena kekuatan politik berputar hanya di lingkaran elit.

\section{Teknis Pilkada Dengan Media Elektronik}

Manusia di era revolusi 4.0, hidup pada dunia real dan virtual. Dualisme dunia inilah membuat manusia tidak hanya berkomunitas di dunia real, melainkan juga dengan dunia virtual. Hal ini berdampak pada manusia postmodern, yang dengan spesialisasi dan kedalaman. Dunia dan budaya siber inilah yang dapat dimanfaatkan untuk menjadi solusi pelaksanaan pilkada langsung di tengah Covid-19. Pilkada langsung yang menggunakan sistem pemilu elektronik. Pemilu elektronik, selama ini sudah didiskusikan di Indonesia, namun masih terbatas pada tataran refleksi. Kunjungan kerja anggota DPR, untuk melihat sistem Pemilu elektronik di beberapa omput, eloknya dibarengi dengan aksi dan implementasi (bukan hanya refleksi). Pemilu elektronik dapat diartikan sebagai sistem pemilihan dengan 
memanfaatkan media elektronik, baik komputer ataupun jaringan internet (Hardjaloka \& Megawati, 2011: 197).

Pemilu elektronik memiliki beberapa keunggulan diantaranya: (1) Hemat biaya, baik dalam proses kampanye ataupun pemilihan; (2) sederhana dan efisien; (3) Waktu yang lebih fleksibel dan efektif; (4) Akurasi kalkulasi ketika penghitungan suara; (5) Meminimalisir terjadinya kecurangan dan tindak pidana Pemilu; (6) Lebih ramah lingkungan, karena mengurangi penggunaan kertas dan tinta kimia; dan terutama (7) mempermudah dan meningkatkan kenyamanan pemilih, terlebih ketika masa pandemiseperti sekarang yang mengharuskan individu untuk menjaga jarak fisik/ physical distancing (Ibid).

Tetapi hal yang harus disadari juga bahwa sebuah sistem elektronik juga memiliki kerentanan yakni: (1) Keamanan dan kerahasiaan, yang mungkin memiliki celah elektronik ataupun diserang secara elektronik; (2) Logistik dan medium, yang mungkin belum tersedia secara merata; (3) Masalah operasional dan kesiapan sumber daya manusia, untuk mengoperasikan sistem elektronik yang ada; (4) Kesenjangan sosial yang masih terjadi, yang memungkinkan tidak menyentuh seluruh kalangan; (5) Kesiapan instrumen hukum terkait pemilihan elektronik, sekalipun Mahkamah Konstitusi pernah mengeluarkan Putusan MK No. 147/PUU-VII/2009 mengenai Pemilu elektronik; dan (6) kesiapan anggaran untuk membangun infrastruktur pemilu elektronik, mengingat fokus pengangaran Indonesia saat ini ditujukan untuk penanganan Covid-19 (Ibid).

\section{Teknis Pilkada Secara Langsung}

Jika dibandingkan dengan angka partisipasi pemilih pada penyelenggaraan pemilu pasca era reformasi (pileg, pilpres dan pilkada) dalam kurun 15 (lima belas) tahun terakhir (1999 sampai 2014), cukup signifikan penurunan angkanya, yakni: Pemilu 1999, tingkat partisipasi pemilih 92,6 persen dan jumlah Golput 7,3 persen; Pemilu 2004, partisipasi pemilih 84,1 persen dan jumlah golput meningkat hingga 15,9 persen; Pilpres Pertama Tahun 2004, putaran pertama tingkat partisipasi politik pemilih mencapai 78,2 persen dan jumlah Golput 21,8 persen, pada putaran kedua sejumlah 76,6 persen dan jumlah golput 23,4 persen; Pemilu Legislatif tahun 2009, tingkat partisipasi politik pemilih 70,9 persen dan jumlah golput yaitu 29,1 persen; Pilpres 2009, tingkat partisipasi politik pemilih mencapai 71,7 persen dan jumlah golput mencapai 28,3 persen; Pemilu 2014, tingkat 
partisipasi pemilih 75,2 persen. Golput 24,8 persen (Mohammad Saihu, $2020: 5$ ).

Pilkada 2020 harus mengantisipasi bahwa pelaksanaan tahapannya tidak dilakukan dalam kondisi benar-benar normal, namun harus menyediakan skenario pelaksanaan dengan menggunakan protocol kesehatan Covid-19. Antisipasi tersebut, antara lain menghindari kerumunan massa, misalnya tahap kampanye. KPU perlu menyiapkan aturan mengenai kampanye secara virtual atau melalui media elektronik. Untuk pengawas, perlu adanya aturan terkait pemberian bantuan sosial agar tidak dimanfaatkan sebagai ajang untuk kepentingan pemilihan. Dan Sebagai bahan pembanding, Korea Selatan merupakan Negara pertama yang melakukan pemilu di tengah pandemi Covid-19. Pemungutan suara dilaksanakantanggal 15 April 2020 kurang lebih di 14.000 TPS. Pemilih diwajibkan menggunakan masker dan dilakukan pengecekan suhu tubuh pada saat kedatangan. Apabila suhu tubuh menunjukkan lebih dari 37,5oC, yang bersangkutan diarahkan ke bilik khusus. Setiap pemilih wajib menggunakan hand sanitizer dan sarung tangan plastik di bilik suara dan menjaga jarak 1 meter antara satu dengan yang lain. Di antara pemilih yang teregistrasi, terdapat 2800 pasien Covid-19. Penyelenggara pemilihan mengizinkan mereka memberikan suaranya melalui surat sebelum pemungutan suara dan membuat TPS khusus (Novianto Murti Hantoro, $2020: 4$ ).

\section{E. Teknis Pelaksanaan Pilkada saat pandemi menurut Perppu 2/2020 dan Peraturan KPU}

DPR dan Pemerintah bersepakat untuk tetap menggelar pemilihan kepala daerah (pilkada) serentak pada 9 Desember 2020 di 270 daerah se-Indonesia . Keputusan ini juga mendasari pada Perppu No 2 Tahun 2020 tentang Pilkada yang telah diteken oleh Presiden Jokowi. Sejumlah tantangan membayangi pelaksanaan pilkada di masa pandemi ini. Kendati pemerintah tengah menyiapkan tatanan normal baru (new normal), hakikatnya ancaman penularan viruas Covid-19 masih terus membayangi. peraturan KPU terkait protokol pelaksanaan pilkada di situasi pandemi memiliki relevansi dan signifikansi yang kuat. Kendati demikian, tantangan berat penyelenggaraan pilkada di momen pandemi ini tidaklah ringan. Dibutuhkan kedisiplinan, kolaborasi, dan komitmen semua pihak agar dari sisi teknis penyelenggaraan pilkada berhasil. Selain itu, pilkada di tengah pandemi harus dipastikan tidak menjadi klaster baru 
penularan virus Covid-19 baik bagi pemilih maupun bagi penyelenggara khususnya petugas pilkada di lapangan.

Didalam Peraturan Komisi Pemilihan Umum Republik Indonesia Nomor 6 Tahun 2020 Tentang Pelaksanaan Pemilihan Gubernur dan Wakil Gurbenur, Bupati dan Wakil Bupati, Wali Kota dan Wakil Wali Kota Serentak Lanjutan Dalam Kondisi Bencana Nonalam Corona Virus Disease 2019 (Covid-19) Bab VIII Bagian Kesatu Pemungutan Suara Pasal 68 Ayat 1 dan 2 hal 61 mengatur Penyelenggaraan Pemungutan Suara dan Penghitungan Suara dalam Pemilihan Serentak Lanjutan dilakukan dengan menerapkan protokol kesehatan pencegahan dan pengendalian Corona Virus Disease 2019 (COVID-19) dengan ketentuan sebagai berikut :

1. Anggota KPPS dan petugas ketertiban TPS mengenakan alat pelindung diri berupa masker yang menutupi hidung dan mulut hingga dagu, sarung tangan sekali pakai, dan pelindung wajah (face shield).

2. Pemilih yang hadir di TPS mengenakan masker yang menutupi hidung dan mulut hingga dagu.

3. KPPS menyediakan sarung tangan sekali pakai untuk digunakan oleh Pemilih.

4. Saksi dan Pengawas TPS yang hadir di TPS mengenakan masker yang menutupi hidung dan mulut hingga dagu, dan sarung tangan sekali pakai.

5. Menjaga jarak paling kurang 1 (satu) meter antarsemua pihak yang terlibat dalam Pemungutan Suara dan Penghitungan Suara.

6. Tidak melakukan jabat tangan dan kontak fisik lainnya.

7. Menyediakan sarana sanitasi yang memadai pada tempat dan/atau perlengkapan yang digunakan untuk kegiatan Pemungutan Suara dan Penghitungan Suara meliputi fasilitas cuci tangan dengan air mengalir dan sabun, dan disinfektan.

8. Mengatur pembatasan jumlah Pemilih yang memasuki TPS dengan mempertimbangkan kapasitas tempat dan ketentuan jarak antar-Pemilih.

9. Wajib menggunakan alat tulis masing-masing.

10. Pelaksanaan rapid test dan pemeriksaan kesehatan kepada anggota KPPS yang dilakukan oleh perangkat daerah yang menangani menyelenggarakan urusan di bidang kesehatan 1 (satu) kali selama tahapan Pemilihan Serentak Lanjutan.

11. Melakukan pengecekan kondisi suhu tubuh anggota KPPS, petugas ketertiban TPS, Pemilih, Saksi, dan Pengawas TPS yang 
hadir di TPS sebelum memasuki TPS dengan menggunakan alat yang tidak bersentuhan secara fisik.

Dalam hal terdapat wilayah yang tidak memiliki fasilitas untuk melaksanakan pemeriksaan rapid test, dapat menggunakan surat keterangan bebas gejala seperti influensa (influenza-like illness) yang dikeluarkan oleh dokter rumah sakit atau otoritas kesehatan.

\section{KESIMPULAN}

Komitmen Indonesia untuk berdemokrasi jangan dicederai oleh kepentingan elite politik. Apalagi melakukannya dengan seolah-olah merujuk pada kepentingan mengatasi pandemi. Pilkada tidak langsung bukan solusi dalam keadaan seperti ini. Sebagai contoh pada saat pemilihan Wakil Gubernur DKI Jakarta yang ditangani DPRD. Kursi Wagub telah kosong sejak akhir 2018 dan pemilihan baru bisa rampung 1,5 tahun setelahnya, Pemerintah tidak dapat memastikan penanganan Covid-19 tuntas pada Juli 2020 dengan kondisi saat ini. Jika pandemi tak kunjung selesai. Pasal 22E ayat (2) UUD 1945, "Pemilihan umum diselenggarakan untuk memilih anggota Dewan Perwakilan Rakyat, Dewan Perwakilan Daerah, Presiden dan Wakil Presiden dan Dewan Perwakilan Rakyat Daerah", yang dilaksanakan secara langsung, umum, bebas, rahasia, jujur, dan adil setiap lima tahun sekali. Hadirnya Perppu No. 2 Tahun 2020 artinya mendukung pelaksanaan Pilkada langsung secara konvensional. Sehingga disatu sisi patut diapresiasi bahwa pemerintah berupaya untuk mewujudkan hak konstitusional warga negara melalui penyelenggaran pilkada. Namun menjadi hal yang patut untuk digaris bawahi ialah terpenuhinya hak-hak seperti hak memilih, hak hidup, dan hak katas memperoleh kesehatan adalah hak asasi manusia (HAM). Untuk mewujudkan itu semua pemerintah pun wajib memastikan protokol kesehatan Covid-19 yang sesuai dengan UU Covid-19 atau secara ketat ketika pelaksanaan proses pilkada.

\section{SARAN}

Dalam hal ini pemerintah harus mempertimbangkan kejadian terburuk dan kemungkinan masalah sosial, ekonomi, politik, dan hukum. Pilkada saat pandemi Covid-19 harus dilakukan pengawasan secara ketat, professional, dan berkonsekuen. Apabila pilkada tetap dilaksanakan harus sesuai protokol Kesehatan dan pengawasan yang maksimal. Sehingga pilkada saat pandemi Covid-19 menjiwai amanat kostitusi yakni dilaksanakan secara langsung, umum, bebas, rahasia, 
jujur, dan adil setiap lima tahun sekali. Penerapan protokol kesehatan ketika pilkada tentu berakibat pada kenaikan anggaran pengeluaran Negara. Tetapi hal ini merupakan tanggung jawab pemerintah agar terpenuhinya hak konstitusional setiap warga masyarakat dan mendapatkan perlindungan kesehatan sesuai dengan cita-cita pendirian Republik Indonesia.

\section{DAFTAR PUSTAKA}

\section{Buku}

Edward Aspinall \& Ward Berenschot, 2019, Democracy for sale: Elections, clientelism, and the state in Indonesia, Ithaca and London: Cornell University Press

Siti Fadilah Supari, 2008, Saatnya Dunia Berubah Tangan Tuhan di Balik Virus Flu Burung, Jakarta: PT. Sulaksana Watinsa Indonesia (SWI).

Soekanto, S, 2002, Faktor-Faktor yang Mempengaruhi Penegakan Hukum, Jakarta: Rajawali Press.

Yuval Noah Harari, 2017, Sapiens Riwayat Singkat Umat Manusia, Jakarta: PT. Gramedia.

Yuval Noah Harari, 2018, Homo Deus 'masa Depan Umat Manusia, Jakarta: PT Pustaka Alvabert.

\section{Peraturan Perundang-Undangan}

Peraturan Komisi Pemilihan Umum Republik Indonesia Nomor 6 Tahun 2020 Tentang Pelaksanaan Pemilihan Gubernur dan Wakil Gurbenur, Bupati dan Wakil Bupati, Wali Kota dan Wakil Wali Kota Serentak Lanjutan Dalam Kondisi Bencana Nonalam Corona Virus Disease 2019 (Covid-19).

Peraturan Pemerintah Pengganti Undang-Undang Republik Indonesia Nomor 2 Tahun 2020 Tentang Perubahan Ketiga Atas UndangUndang Nomor 1 Tahun 2015 Tentang Penetapan Peraturan Pemerintah Pengganti Undang-Undang Nomor 1 Tahun 2014 Tentang Pemilihan Gubernur, Bupati, Dan Walikota Menjadi Undang-Undang

Undang-Undang Republik Indonesia Nomor 10 Tahun 2016 Tentang Perubahan Kedua Atas Undang-Undang Nomor 1 Tahun 2015 Tentang Penetapan Peraturan Pemerintah Pengganti UndangUndang Nomor 1 Tahun 2014 Tentang Pemilihan Gubernur, Bupati, Dan Walikota Menjadi Undang-Undang 
Undang-Undang Dasar Republik Indonesia Tahun 1945

Undang-Undang Republik Indonesia Nomor 8 Tahun 2015 Tentang Perubahan Atas Undang-Undang Nomor 1 Tahun 2015 Tentang Penetapan Peraturan Pemerintah Pengganti Undang-Undang Pemilihan Gubernur, Bupati, Dan Walikota Menjadi UndangUndang.

\section{Jurnal}

Andrian Habibi, 2020, "Pemilihan Umum Di Tahun 2020", Jurnal Buletin Hukum dan Keadilan, Vol. 4, No.1 UIN Syarif Hidayatullah Jakarta.

Djoharis Lubis, 2020, "Pilkada serentak 2020 di tengah gelombang pandemi covid-19: apakah menghasilkan Kepemimpinan yang efektif berbasis multikultur?", Jurnal Kajian Lemhannas RI Edisi 42.

Hutapea, B., 2015, "Dinamika Hukum Pemilihan Kepala Daerah di Indonesia", Jurnal Recht Vindings, Vol. 4, No.1

Hardjaloka, L., 2015, "Studi Dinamika Mekanisme Pilkada di Indonesia dan Perbandingan Mekanisme Pilkada Negara Lainnya", Jurnal RechtsVinding, Vol. 4, No.1

Mohammad Saihu, 2019, "Pengembangan Pemilu Berintegritas Hukum Kode \& Etik", Jurnal Etika \& Kode Etik Pemilu Vol. 5, No.1

Novianto Murti Hantoro, 2020, "Tindak Lanjut Perppu Penundaan Pilkada", Jurnal Kajian Singkat Terhadap Isu Aktual Dan Strategis, Vol. XII, No.10

Rezky Panji Perdana Martua Hasibuan, 2020, "Urgensitas Perppu Pilkada Di Kala Wabah Pandemi Covid-19", Jurnal "Adalah: Buletin Hukum dan Keadilan, Vol. 4, No.1, UIN Syarif Hidayatullah Jakarta.

Rahman Yasin, 2019, "Pengembangan Pemilu Berintegritas Hukum Kode \& Etik", Jurnal Etika \& Kode Etik Pemilu Vol. 5, No.1

Richard Kennedy, Bonaventura Pradana Suhendarto, "Diskursus Hukum: Alternatif Pola Pengisian Jabatan Kepala Daerah di Masa Pandemi Covid-19", Jurnal Pembangunan Hukum Indonesia Program Studi Magister Ilmu Hukum Vol 2 No. 2 Fakultas Hukum Universitas Diponegoro. 
Saraswati, R., 2011, "Calon Perseorangan: Pergeseran Paradigma Kekuasaan dalam Pemilukada", Jurnal Masalah-Masalah Hukum, Vol. 40, No. 24

Sodikin. 2015, "Pemilihan Kepala Daerah dalam Konteks UUDN RI Tahun 1945", Jurnal Rechts Vinding, Vol. 4, No.1

Siti Chadijah, 2020, "Harmoisasi Kewenangan Penanganan Pandemi Covid-19 Antara pemerintah Pusat Dan Daerah", Jurnal Kertha Semaya, Vol.8 No. 6

\section{Artikel Internet}

International Institute for Democracy and Electoral Assistance, Ikhtisar Global COVID-19, "Dampak terhadap Pemilu”, Retrieve from https://Www.idea.int/sites/default/files/multimed ia_reports/13052020-overview-elections andcovid-19-bahasaindonesia.pdf.

Penundaan Pilkada Serentak 2020 Ditengah Pandemi Covid-19", https://jurnalintelijen.net/2020/04/24/dampak-penundaanpilkada-serentak-2020-ditengah-pandemi-covid-19/,diunduh April 24, 2020.

perludem.org, "Pilkada Di Tengah Pandemi Butuh Kerangka Hukum", https://republika.co.id/berita/qbyet9396/perludem-pilkada-ditengah-pandemi-butuh-kerangka-hukum, diunduh 16 Juni 2020 . 